\title{
Biological applications of honeys produced by Apis mellifera
}

\author{
Gloria Montenegro* and Enrique Mejías* \\ * Departamento de Ciencias Vegetales, Facultad de Agronomía e Ingeniería Forestal, Pontificia Universidad Católica de Chile. Av. Vicuña Mackenna 4860, Macul, Santiago, \\ Chile. Postal Code: 6904411 - Phone: 56223547216 Fax: 56225520780.
}

\begin{abstract}
Honey is a natural product with many attributes that are useful for humans. The consumption of honey is increasing because of its beneficial biological properties, including antioxidant and antibacterial activities. Even though honey is produced worldwide, many variants of this product have not been studied and their biological potential for alternative uses has not been evaluated. Because of its varied endemic native flora, Chile produces several types of honey. It is likely that these apian products have important biological properties inherited from specific floral sources, but it is absolutely necessary to conduct further chemical analyses to identify and characterize these biological attributes. Sadly, the potential antimicrobial and antitumor activities of Chilean honeys remain unproven at the present time. Further studies are needed to identify these attributes. In addition, the impact of human activities on the natural production of honey by bees should be considered. The use of honey as an environmental marker of pollution should also be considered, and care must be taken to diminish the effect of industry and human procedures on natural environments
\end{abstract}

Key words: Honeys, Antioxidants, Natural Antibiotics, Environmental Bioindicator

\section{INTRODUCTION}

Honey has been defined as a natural sweet mixture produced by honeybees from the nectar of flowers or from living parts of plants. Bees combine this mixture with substances of their own and the mixture is deposited, dehydrated and stored in the honeycomb for further use (Codex Stan 12$1981 / 2001$ ). Honey is the best-characterized apian product, due to its nutritional value and the fact that it is a natural food (Gheldof and Engeseth, 2002). Honey is composed of several carbohydrates, especially fructose and glucose (85 to $95 \%$ of total sugars). Glucose has a lower degree of solubility than fructose and the ratio of glucose to fructose determines the liquid state of a given honey. Other types of sugar can be present due to the union of two or more molecules of fructose or glucose to form polysaccharides (Ojeda de Rodríguez et al., 2004). Additionally, other substances are present in honey such as organic acids, amino acids, proteins, enzymes, lipids, flavonoids and vitamins that are responsible for its biological properties (including antioxidant and antibiotic activities) (Mendes et al., 1998; González et al., 2000; Terrab et al., 2002; Meda et al., 2005; Finola et al., 2007).

Melissopalynological analyses are used to establish whether a honey is unifloral. Unifloral honey has a higher market price because at least $45 \%$ of the pollen grains in its solids are from one plant species (Montenegro et al., 1992; 2005; 2008a). Thus the quality of a honey depends on the presence and concentration of specific compounds and the botanical origin classification (Montenegro et al., 2003; 2006; 2008b). Honey can have characteristics of the pollen grains, nectar and plants that were visited by the bees and used to make the honey. Thus the biological properties of honey are related to the plant species and its attributes (NCh 298. Of 2005). Antioxidant activity is one such biological property of honey. The presence of enzymatic antioxidants (glucose oxidase, catalase) and non-enzymatic antioxidants (flavonoids, ascorbic acid and phenolic acids) has been detected in many honeys (Aljadi and Kamaruddin, 2004; Marguitas et al., 2009). Antibacterial properties have also been described for honeys produced in different places. The antimicrobial activity of honey is due to several parameters, including osmolarity, $\mathrm{pH}$ and the production of $\mathrm{H}_{2} \mathrm{O}_{2}$ and other chemical compounds. In addition, differences among honeys may be attributed to geographical origin, harvesting season, storage conditions and the botanical sources that are responsible for these biological activities (Sherlock et al., 2010). In this review we aim to illustrate the current advances in research related to honey and its natural properties and discuss important applications and uses of this product in biotechnology, medicine and food and environmental studies.

\section{NATURAL ANTIBIOTIC}

Several unifloral honeys produced around the world have a wide spectrum of antibacterial properties against human microbiological pathogens. Manuka honey produced from the tree Leptospermum scoparium is known to have some of the most effective natural antibiotic effects against approximately 60 species of bacteria, including aerobes and anaerobes and Gram positives and Gram negatives. This powerful inhibitory effect of Manuka honey is related to the increased osmolarity, high acidity and high methylglyoxal (MGO) content of the honey (Mandal and Mandal 2011).

Visavadia et al. (2008) showed that Manuka honey has important antibacterial properties that can be used in patients with injuries infected with methicillin-resistant Staphylococcus aureus. Similarly, in vitro assays showed that honey from Ireland decreased the presence of this strain of bacteria (Maeda et al; 2008). Similar in vitro studies conducted with Manuka and Sidr honey have shown that dilutions of these samples 
were able to limit the growth of strains of Staphylococcus aureus and Pseudomonas aeruginosa (Alandejani et al; 2009). Chemical analyses of several Manuka honeys identified three major constituents that appear to be responsible for the described biological activities of these honeys: phenyllactic acid, methyl syringate and a methoxylated benzoic acid. The amount of each compound may be modified after heating. In addition, the methoxylated compounds in Manuka honey differ with the age of the honey (Stephens et al., 2010).

The antimicrobial properties of honeys have also been related to the presence of other chemical compounds such as flavonoids and phenolics. One of the strategies for inhibiting the growth of bacteria in food is to prevent the interaction between the bacteria and the food matrix, decreasing food spoilage. An analysis of twenty nine unifloral samples of European honeys showed an interesting correlation between antibacterial properties and the ability of the honey to inhibit quorum sensing (QS) (or the cellto-cell communication) of the bacteria. In this case, however, total phenolic compounds were not directly related to this ability to reduce spoilage (Truchado et al., 2009).

Despite the important differences in the botanical composition and thus the chemical profiles of many unifloral honeys, several authors have concluded that the antibacterial performance of honey is associated with the phenolic content of the honey. The biological properties of fifty samples of Rhododendron honey produced in the Black Sea region of Turkey were studied. The antibacterial activity of the honey was found to be partially correlated with the phenolic content of each analyzed sample. However, even when the selected honeys belonged to the same unifloral species, the phenolic content was strongly affected by the final percentage of Rhododendron in the total floral residual composition. In addition, the geographical origin and the climatic characteristics of the region played an important role that may have affected the efficiency of the phenolic compounds against bacteria. This finding could explain the differences in these honeys (Silici et al., 2010).

Although the best-characterized honeys around the world are unifloral samples, multifloral honeys have also been found to have important biological activities. In Argentina (one of the most important producers of honey in the world), studies have aimed to analyze the attributes of both unifloral and multifloral honeys. The antibiotic properties of several honeys against human pathogenic bacteria such as Staphylococcus aureus, Enterococcus faecalis, Pseudomona aeruginosa, Escherichia coli, Morganella morganii and Klebsiella pneumonia were studied. In every assay, it was possible to identify a group of unifloral and multifloral honeys with important antibacterial properties. In both cases, the antibacterial properties were correlated with the total phenolic content of the honey (Isla et al., 2011).

In Chile, several studies have identified the botanical origins of native Chilean honeys and their physical-chemical attributes, which are essential for characterizing the biological properties of the honey.

In the case of Ulmo (Eucryphia cordifolia) honey, approximately 20 peaks appeared in chromatographic studies and 10 of them have been identified. The peaks that appeared most frequently corresponded to caffeic, chlorogenic, salicylic and p-coumaric acids (this last compound was found at very low concentrations) and esculetin, escopoletin and quercetin flavonoids (this last compound was also found at very low concentrations) (Muñoz et al., 2007).
Other studies of Quillay honey have shown a relationship between the content of phenolic compounds and the antioxidant and antibacterial activities of the honey. Quillay honey had higher levels of antioxidant activity than other Chilean unifloral honeys. The concentrations of polyphenols were measured according to the total content determined by the Folin-Ciocalteau method in the chromatograms of this honey obtained by HPLC; approximately 40 peaks appeared (each corresponding to a different compound) but fewer than 15 have been effectively identified. The most commonly appearing compounds were phenolic acids (chlorogenic, ferulic, gallic and salicylic acids) and flavonoids such as kaempferol, naringenine and rutine (Montenegro et al. 2006; Muñoz et al; 2007).

The most recent study of the biological properties of Chilean honeys showed that the presence of other species in the total botanical content of honey plays an important role in the modulation of its biological properties. In particular, the chemical composition and antibacterial capabilities of Ulmo honey (Eucryphia cordifolia), Quillay honey (Quillaja saponaria), Avellano honey (Gevuina avellana) and Tiaca honey (Caldcluvia paniculata) were analyzed; the methanolic extract of these honeys had better antibacterial capabilities than the honeys themselves. In in vitro assays, all of the obtained extracts were able to inhibit the growth of Escherichia coli, Pseudomonas aeruginosa, Staphylococcus aureus and Streptococcus pyogenes (Montenegro et al., 2013).

As mentioned previously, phenolic compounds are determined by botanical origin and the differences in unifloral honeys are mainly determined by geographical conditions. Estevinho et al. (2008) analyzed the ethanol extracts from two unifloral honeys produced in Portugal and found that phenolic compounds were responsible for the antibacterial and antioxidant properties of those honeys; however, the differences in biological activity (and therefore phenolic profiles) of the extracts could be explained by the different geographical places of origin.

Honeys with antibacterial activity could be used as an alternative treatment against multi-drug resistant pathogens. Arabian honeys such as Acacia honey have shown effectiveness against the following bacteria isolated from humans: Escherichia coli, Staphylococcus aureus, Bacillus subtillis, Pseudomona aeruginosa, Klebsiella pneumonia, Salmonella typhimurum, Micrococcus luteus, Staphylococcus epidermidis, Bacillus cereus, Aspergillus nidulans, Serratia marcescens and Enterobacter aerogene. Another advantage of honey is that a low dose is required for antibacterial effect. In addition, the natural origin of this apian product reduces the chances of a cross reaction with undesirable effects in the patient receiving these alternative treatments for bacterial diseases (AlWaili et al., 2013).

\section{NATURAL ANTIOXIDANT}

One of the best-characterized natural attributes of honey is its antioxidant property. As mentioned previously, honeys contain several bioactive compounds such as enzymes, organic acids, carotenoids and phenols. The chemical composition and antioxidant capabilities of the honey are directly related to the floral sources, environmental conditions and the post-harvest processing. In addition, the intensity of the color of a honey may be associated with the antioxidant strength of the honey. The phenolic, flavonoid and carotenoid content is increased 
in darker honeys and reduced in lighter more transparent honeys. As a result, biological properties (such as antioxidant activities and antibacterial capabilities) of the honey are related to its color, and darker honeys tend to have enhanced properties (Álvarez- Suárez et al., 2010). A comparison study carried out with 24 samples of Romanian honeys with different botanical origins showed a direct correlation between the antioxidant activity and the concentration of phenols in the samples. Honeydew honey had the best antioxidant performance and the highest concentrations of total phenols and total flavonoids. It is important to note that every studied sample had some degree of antioxidant capability; however, in all cases, the honeys with greater amounts of these molecules had the highest activities (Liviu Al et al., 2009). In a similar study, three unifloral honeys from northeastern Portugal had good antioxidant activities that differed with the phenolic extract measured in the honey after processing. This result suggests that even if a good extraction procedure for phenolic compounds is used, other molecules remain in the honey that could act as complements of phenolic compounds and thereby improve the antioxidant activity of the honey. This would explain why the extracts have lower antioxidant capabilities than the original honey (Ferreira et al., 2009).

It is important to emphasize that the antioxidant activity may be determined more by protein content than by phenolic compounds. In India, the physical-chemical characteristics and antioxidant activities of seven honeys obtained from a supermarket were characterized. The samples had a wide range of antioxidant activities but there was no clear correlation between this attribute and the total phenolic content of the honey. In contrast, the protein content and the concentration of proline were found to be statistically significantly correlated with the antioxidant properties of the honey (Saxena et al., 2010).

Similar studies have characterized honeys from a specific country or region. The differences among the samples of honey were found to be determined by two principal aspects: the composition and percentage of floral residues and the amount of bioactive phenolic compounds. This latter finding is remarkable, because after comparing two different samples of honey with similar total phenolic contents, significant differences were found in the antioxidant activities associated with the nature of each phenolic profile. Therefore, to assess this biological property accurately a complete antioxidant assay after phenolic quantification is necessary (Lachman et al., 2010).

Recently, the increasing use of honey around the world has produced interest in characterizing the quality of a honey by identifying and quantifying these bioactive molecules. The organoleptic properties of a given honey are determined by the ratio of these molecules. It is therefore important to analyze both parameters to produce a tasty honey with desirable biological properties. In addition, these molecules may be used as markers of the geographical origin of the honey (Alqarni et al., 2013). It is therefore necessary to improve the analysis of these phenolic compounds by chromatographic analysis or an equivalent technique. Quillay honey is a Chilean honey with potent antioxidant activities inherited from a variety of vegetable species. The identification of gallic acid and salicylic acid in eight samples of unifloral Quillay honey by capillary electrophoresis with diode array detector (CE-DAD) enabled the establishment of a reference profile of these compounds with a similar ratio in all the studied samples. The same compounds were also detected in nectar from the flowers of Quillaja saponaria and from the ethanolic extraction of the honey sac from the beehives where the honeys were produced. These data resulted in an important advance in the characterization of the phenolic profile of a native Chilean honey with antioxidant activity (Mejias et al., 2012). In contrast, the phenolic profile of Jandaíra (Melipona subnitida) honey produced by the stingless bee Melipona subnitida was analyzed by HPLC-DAD. This honey is produced in northeastern Brazil and widely used for its medicinal properties even though it is not included in the International Standard for Honey (Codex Stan 12-1981/2001). The analysis of the phenolic profiles of nine samples of this honey showed that the flavonoids naringenin, quercetin, and isorhamnetin were regularly present. In addition, gallic, vanillic, 3,4-dihydroxybenzoic and cumaric acids were detected (Sarmento Silva et al. 2013). In both Quillay honey and Jandaíra honey, the chemical identification of phenolic compounds associated with the biological activities of the honey is a useful tool; in addition, this type of analysis may help certify the geographical origin of honeys.

\section{BIOINDICATOR OF ENVIRONMENTAL POLLUTION}

Honeys can inherit the attributes of the floral sources responsible for their botanical origin (NCh 298. Of2005). For this reason, it is possible to detect certain undesirable compounds and/ or residual molecules from different human activities. These pollutants can be deposited onto the surfaces of melliferous plants and flowers, especially in the case of plants growing near industries, highways or volcanoes (Mejias et al., 2009).

Metals are listed among the pollutant residues that can be detected in the final composition of honeys. They can be toxic for human beings if found at levels over the permitted limits (AAFCO, 1996)

Some studies have sought to establish the relationship between the metal content and the biological properties of honey (Baroni et al., 2009; Pohl, 2009). Early results were obtained by Jones (1987) who analyzed honeys produced in the United Kingdom. The aim of this work was to determine if any of these honeys could be used as a bioindicator of environmental pollution. Honey samples and soil samples from where the beehives were located were processed by wet digestion and analyzed by atomic absorption spectroscopy (AAS). This first approach did not detect a strong correlation between the pollutants in honey and the pollutants in the soils. However, because metals are present in very low concentrations in the honeys, this analytical procedure may not have been appropriate, as any loss of sample during the analysis may have an important effect on the final results.

Przybylowski and Wilczynska (2001) examined honeys with different botanical origins produced in Poland to establish a connection between quality parameters (such as $\mathrm{pH}$, glucose/fructose ratio, humidity, electric conductivity, amount of hydroxymethylfurfural (HMF) and the presence of cadmium, lead and zinc) and metals. The analytical methodology used in this study was based on the proposal of the Association of Analytical Communities (AOAC) International $(970.20 ; 2000)$. However, these authors did not find a clear association between metals and the parameters assessed. Nevertheless, the low presence of cadmium and lead in honeys from the same geographical origin allowed 
the authors to deduce that a certain degree of environmental pollution had occurred in that region.

In another study, the metal contents of 81 honeys from the Canary Islands were studied. The data from these honeys were compared with data obtained from 35 samples of honey from other regions of Europe. The concentrations of alkali and alkali earth metals in these honeys were found to be at the same level as those of honeys produced in Spain. As a result, the author concluded that chemical determinations would be useful for the certification of the geographical origin of honeys. In addition, chemical analyses would constitute an important tool for determining the presence of environmental pollution (Hernández et al. 2005).

A similar trend was found in an analysis of different samples of avocado honey from Spain. In this study, the metal content in honeys allowed the authors to identify the geographical origins of the samples. Unfortunately, these studies were restricted to unifloral honeys. In addition, it is necessary to analyze a large number of samples of the same honey to identify its chemical profile. The association between the botanical origin and metal content of honey remains unclear (Terrab et al. 2005). Fredes and Montenegro (2006) studied the potential correlation between botanical origins and metal contents in Chilean honeys produced throughout the country. After several analyses, the metal contents of honeys with similar botanical origins had an increased deviation. Thus, even if the metal content of honey was a marker of pollution in the environment, it was not able to determine the botanical origin of the honey. Instead, it would be interesting to determine how metallic elements modify the natural properties or attributes of a given honey.

Some authors have tried to detect the changes in the natural antibacterial activity of honeys caused by metals. The metallic composition and the effect on the antibacterial activities of a group of honeys produced in Turkey were analyzed. The microbiological assays showed that honeys with higher metallic contents had more potent antibacterial properties. In all of the studied samples, the presence of metals did not exceed the permitted limits of the relevant elements in honeys and food (Küçük et al. 2007).

Recently, the effect of metals on the antioxidant properties of honeys produced near the Llaima Volcano was analyzed. Samples of Lotus uliginosus honey were studied to identify the presence of copper $(\mathrm{Cu})$, magnesium $(\mathrm{Mg})$, zinc $(\mathrm{Zn})$, iron $(\mathrm{Fe})$, cadmium $(\mathrm{Cd})$, chromium $(\mathrm{Cr})$ and lead $(\mathrm{Pb})$. Subsequently, the antioxidant activities of the selected honeys were measured. In this study, the levels of $\mathrm{Cu}, \mathrm{Mg}$ and $\mathrm{Fe}$ were higher in the Llaima samples than in the control samples. Similarly, the honeys with the highest metal content had the lowest levels of antioxidant activity. A negative correlation between the concentration of each element and the antioxidant parameters confirmed the effect of the metals on the natural antioxidant properties of the honeys. The most important contribution of this study was to establish an indirect way to assess the impact of polluted environments on natural products produced or processed near the source of pollution (Mejias and Montenegro, 2012).

\section{SUMMARY}

Honey is a natural product with many attributes useful for human beings. Nowadays, the consumption of honey is increasing due to its described biological properties such as antioxidant and antibacterial activities. However, honey is produced around the world and there still are many samples of this product that have not been studied or characterized in terms of their biological potential or alternative uses.

Chile produces several kinds of honey, owing to the presence of a diverse endemic native flora. These bee products appear to have important biological properties inherited from specific floral sources, but further chemical analyses directed to determine the presence of biological attributes are absolutely necessary. Sadly, many potential effects against bacteria, fungi or antitumor or antiviral activities remain unknown at the present time. Further studies may reveal those attributes in the future.

Another fact to be considered is the human activities that may affect the natural production of honey by bees. Despite the limited usefulness of honeys as environmental markers of pollution, they warn that industrial and human procedures should aim to decrease their impact on natural environments.

\section{ACKNOWLEDGMENTS}

This work was supported by MECESUP PUC0815 to the Pontificia Universidad Católica de Chile, FONDECYT Grant Number 1110808 to Gloria Montenegro and VRI - PUC Grant INICIO/16/2013 to Enrique Mejías.

\section{REFERENCES}

AAFCO (1996) Association of American Feed Control Officials. Official Publication. p. 230.

ALANDEJANI T, MARSAN J, FERRIS W, SLINGER R. and CHAN F. (2008) Effectiveness of honey on Staphylococcus aureus and Pseudomonas aeruginosa biofilms. Otolaryngology - Head and Neck Surgery. 139(2); Suppl 1 - P107

ALQARNI A, OWAYSS A and MAHMOUD A. (2012) Physicochemical characteristics, total phenols and pigments of national and international honeys in Saudi Arabia. Arabian Journal of Chemistry. In Press

ALJADI AM, \& KAMARUDDIN MY. (2004). Evaluation of the phenolic contents and antioxidant capacities of two Malaysian floral honeys. Food Chemistry, 85(4), 513-518

ALVAREZ-SUAREZ JM, TULIPANI S, DÍAZ D, ESTEVEZ Y, ROMANDINI S, GIAMPIERI F, DAMIANI E, ASTOLFI P, BOMPADRE S. and BATTINO M. (2010) Antioxidant and antimicrobial capacity of several monofloral Cuban honeys and their correlation with color, polyphenol content and other chemical compounds. Food and Chemical Toxicology 48: 2490-2499.

AL-WAILI N, AL GHAMDI A, JAVED ANSARI M, AL-ATTAL Y, ALMUBARAK A. and SALOM K. Differences in composition of honey samples and their impacto $\mathrm{n}$ the antimicrobial activities against drug multiresistant Bacteria and Pathogenic Fungi. Archives of Medical Research 44: 307-316.

AOAC - Official Methods of Analysis. 2000. Plants: In: Horwitz, W. (ed.). Official Methods of Analysis of AOAC International. Maryland, USA. $1(3): 4-5$.

BARONI M, ARRUA C, NORES ML, FAYÉ P, DIAZ M, CHIABRANDO G. and WUNDERLIN D. (2009) Composition of honey from Córdoba (Argentina): Assessment of North/South provenance by chemometrics. Food Chem 114: 727-733

Codex Stan 12-1981. Revised Codex Standard for Honey. Codex Stan 121981, Rev.1 (1987), Rev. 2 (2001).

ESTEVINHO L. PEREIRA A, MOREIRA L. and DIAS L. (2008) Antioxidant and antimicrobial effects of phenolic compounds extracts of Northeast Portugal Honey. Food and Chemical Toxicology 46: 3774-3779.

FERREIRA I, AIRES E, BARREIRA J. and ESTEVINHO L. (2009) Antioxidant activity of Portuguese honey samples: Different contributions of the entire honey and phenolic extract. Food Chemistry 114: 1438-1443.

FINOLA MS, LASAGNO MC. and MARIOLI JM. (2007) Microbiological and chemical characterization of honeys from central Argentina. Food Chemistry 100: 1649-1653. 
FREDES C. and MONTENEGRO G. (2006) Contenido de metales pesados y otros elementos traza en mieles de abeja en Chile. Cien Inv Agr 33:57-66.

GHELDOF N. and ENGESETH NJ. (2002) Antioxidant capacity of honeys form various floral sources based on the determination of oxygen radical absorbance capacity and inhibition of in vitro lipoprotein oxidation in human serum samples. J. Agricultural and Food Chemistry 50: 3050-3055

GONZÁLEZ PARAMÁS A, GÓMEZ JA, GARCÍA VILLANOVA R, RIVAS T, ARDANUY R. and SÁNCHEZ J. (2000) Geographical discrimination of honeys by using mineral composition and common chemical quality parameters. J Sci Food Agric 80:157-165

HERNÁNDEZ OM, FRAGA JMG, JIMÉNEZ AI, JIMÉNEZ F. and ARIAS JJ. (2005) Characterization of honey from Canary Islands: determination of the mineral content by atomic absorption spectrophotometry. Food Chemistry 93: 449-458.

ISLA MI, CRAIG A, ORDÓÑEZ R, ZAMPINI C, SAYAGO I, BEDASCARRASBURE E, ÁLVAREZ A, SALOMON V. and MALDONADO L. (2011) Physico chemical and bioactive properties of honeys from Northwestern Argentina. LWT - Food Science and Technology. 44: 1922-1930.

JONES KC. 1987. Honey as an indicator of heavy metal contamination. Water, Air and Soil Pollution 33:179-189.

KÜÇÜK M, KOLAYI S, KARAOGLU S, ULOSOY E, BALTACI C, and CANDAN F. (2007) Biological activities and chemical composition of three honeys of different types of Anatolia. Food Chemistry 100: 526-534.

LACHMAN J, ORSÁK M, HEJTMÁNKOVÁ A. and KOVÁROVÁ E. (2010) Evaluation of antioxidant activity and total phenolics of selected Czech honeys. LWT - Food Sci.Technol. 43, 52-58.

LIVIU AL M, DANIEL D, MOISE A, BOBIS O, LASLO L. and BOGDANOV S. (2009) Physico-chemical and bioactive properties of different floral origin honeys from Romania. Food Chemistry 112: 863-867.

MANDAL M. and MANDAL S. 2011. Honey: its medicinal property and antibacterial activity. Asian pacific Journal of Tropical Biomedicine. 154-160.

MAEDA Y, LOUGHREY A, PHILIP EARLE JA, MILLAR C, RAO J, KEARNS A, MCCONVILLE O, GOLDSMITH C, ROONEY P, DOOLEY J, LOWERY C, SNELLING W, MCMAHON A, MCDOWELL D. and MOORE J. (2008) Antibacterial activity of honey against communityassociated methicillin- resistant Staphylococcus aureus (CA_MRSA). Complementary Therapies in Clinical Practice. 14: 72-82

MARGUITAS L, STANCIU O, DEZMIREAN D, BOBIS O, POPESCU O, BOGDANOV S. and CAMPOS M. (2009) In Vitro antioxidante capacity of honeybee-collected pollen of selected floral origin harvested from Romania. Food Chemistry 115: 878-883

MEDA A, LAMIE C, ROMITO M, MILLOGO J.and NACOULMA OG. (2005) Determination of the total phenolic, flavonoid and proline contents in Burkina Fasan honeys, as well as their radical scavenging activity. Food Chemistry 91:571-577.

MEJÍAS E, GAREIL P, DELAUNAY N. and MONTENEGRO G. (2012) Chemical markers of Chilean monofloral honey bee identified by capillary electrophoresis (CE). Planta Medica.78 (11):1119-1120.

MEJÍAS E. and MONTENEGRO G. (2012) The antioxidant activity of Chilean honey and bee pollen produced in the Llaima Volcano's zones. Journal of Food Quality 35 (5): 315-322.

MEJÍAS E, OLIVARES L, SALAS F. and MONTENEGRO G. (2009) Miel de abejas: un bioindicador natural de contaminación ambiental. Revista Agronomía y Forestal FAIF-PUC 37, 10-13.

MENDES E, BROJO-PROENÇA E, FERREIRA IMPLVO. and FERREIRA MA. 1998. Quality evaluation of portuguese Honey. Carbohydrate Polymers 37:3:219-223.

MONTENEGRO G. (Ed). (1992) Flora de interés apícola en Chile. Libro de difusión editado por la Facultad de Ciencias Biológicas de la P. Universidad Católica de Chile. 56 pp.

MONTENEGRO G, PIZARRO R, ÁVILA G, CASTRO R, RÍOS C, MUÑOZ O, BAS F and Gómez M. (2003) Origen botánico y propiedades químicas de las mieles de la Región Mediterránea árida de Chile. Ciencia e Investigación Agraria 30(3): 161-174.

MONTENEGRO G, PIZARRO R, ÁVILA G, MUÑOZ O, MUJICA AM. and BAS F. (2005) Determination of the botanical origin and some chemical properties of honeys from the central zone of Chile. Phyton (International Journal of Experimental Botany) 74: 213-223.

MONTENEGRO G. (2006) International Patent Customer Number 23599 "Natural composition based on Chilean unifloral honey extract from native plant species for bacterial infection control in vegetables at all".

MONTENEGRO G, GÓMEZ M, DÍAZ-FORESTIER J. and PIZARRO R. $\left(2008^{a}\right)$ Aplicación de la Norma Chilena Oficial de denominación de origen botánico de la miel para la caracterización de la producción apícola. Cien Inv Agr 35 (2): 181-190.

MONTENEGRO G, GÓMEZ M, PIZARRO R, CASAUBON G, and PEÑA R. (2008b) Implementación de un panel sensorial para mieles chilenas. Ciencia e Investigación Agraria 35(1): 51-58

MUÑOZ O, COPAJA S, SPEISKY H, PEÑA R. and MONTENEGRO G. (2007) Contenido de flavonoides y compuestos fenólicos de mieles chilenas e índice antioxidante. Quim Nova 30 (4): 848-851.

MONTENEGRO G, SANTANDER F, JARA C, NÚÑEZ G, and FREDES C. (2013) Actividad antioxidante y antimicrobiana de mieles monoflorales de plantas nativas chilenas. Bol Latinoam Caribe Plant Med Aromat 12(3): 257-268.

Norma Chilena NCh2981. Of (2005) Miel de abejas - Denominación de origen botánico mediante ensayo melisopalinológico. Instituto Nacional de Normalización.

Norma Chilena Oficial NCh 3142 Of (2008) Miel de abejas - Determinación del contenido de metales pesados - Método de plasma acoplado inductivamente ICP.

OJEDA DE RODRÍGUEZ G, SULBARÁN DE FERRER B, FERRER A. and RODRÍGUEZ B. (2004) Characterization of Honey produced in Venezuela. Food Chemistry 84:499-502.

POHL P. (2009) Determiantion of metal content in honey by atomic absorption and emission spectrometries. Trends in analytical Chemistry 28 (1): $117-128$

PRZYBYLOWSKY P. and WILCZYNSKA A. (2001) Honey as an environmental marker. Food Chemistry 74:289-291.

SARMENTO SILVA TM, PEREIRA DOS SANTOS F, EVANGELISTARODRIGUES A, SARMENTO DA SILVA EM, SARMENTO DA SILVA G, SANTOS DE NOVAIS J, RIBEIRO DOS SANTOS FA. and AMORIN CAMARA C. (2013) Phenolic compounds, melissopalynological, physicochemical analysis and antioxidant activity of jandaíra (Melipona subnitida) honey. Journal of Food Composition and Analysis 29: 10-18.

SAXENA S, GAUTAM S, and SHARMA A. (2010) Physical, biochemical and antioxidant properties of some Indian honeys. Food Chemistry 118: 391-397.

SHERLOCK O, DOLAN A, ATHMAN R, POWER A, GETHIN G, COWMAN S. and HUMPHREYS H. (2010) Comparison of antimicrobial activity of Ulmo honey from Chile and Manuka honey against methicillin-resistant Staphylococcus aureus, Escherichia coli and Pseudomonas aeruginosa. Complementary and Alternative Medicine. 10:47.

SILICI S, SAGDIC O. and EKICI L. (2010) Total phenolic content, antiradical, antioxidant and antimicrobial activities of Rhododendron honeys. Food Chem. 121, 238-243.

STEPHENS I, SCHLOTHAUER $R$, MORRIS B, YANG D, FEARNLEY L, GREENWOOD D, and LOOMES K. (2010) Phenolic compounds and methylglyoxal in some New Zealand manuka and kanuka honeys. Food Chemistry 120:78-86.

TERRAB A, DIEZ M. and HEREDIA FJ. (2002) Characterization of Moroccan unifloral honeys by their physicochemical characteristics. Food Chemistry 79:373-379.

TERRAB A, RECAMALES AF, GONZÁLEZ-MIRET ML and HEREDIA FJ. (2005) Contribution to the study of avocado honeys by their mineral contents using inductively coupled plasma optical emisión spectrometry. Food Chemistry 92: 305-309.

TRUCHADO P, FERRERES F. and TOMAS-BARBERAN F. (2009) Liquid chromatography-tandem mass spectrometry reveals the widespread occurrence of flavonoid glycosides in honey, and their potential as floral origin markers. J. Chromatogr A 1216: 7241-7248.

VISAVADIA B, HONEYSETT J. and DANFORD M. (2008) Manuka honey dressing: An effective treatment for chronic wound infections. British Journal of Oral and Maxillofacial Surgery. 46: 55-56. 
